\title{
Motion Graphic Iklan Layanan Masyarakat Edukasi Tata Tertib Rambu Lalu Lintas
}

\author{
Muhammad Ilham1, Muchammad Fajri Amirul Nashrullah ${ }^{2}$ \\ * Informatics Engineering, Batam State Polytechnic \\ ** Multimedia and Network Engineering, Batam State Polytechnic
}

\section{Article Info \\ Article history: \\ Received Jun $12^{\text {th }}, 2021$ \\ Revised Jun $20^{\text {th }}, 2021$ \\ Accepted Jul 26 ${ }^{\text {th }}, 2021$}

Keyword:

Motion Graphic

Video

Kinetic Typography

\begin{abstract}
Iklan layanan masyarakat ialah iklan yang menyajikan pesan-pesan sosial yang bertujuan untuk membangkitkan kepedulian masyarakat terhadap sejumlah masalah yang harus mereka hadapi, yakni kondisi yang bisa mengancam keselarasan dan kehidupan umum. Kurangnya kesadaran oleh pengendara sepeda motor seringkali berakibat fatal terhadap dirinya dan bahkan orang lain. Bahkan banyak dari pengendara sepeda motor melanggar peraturan yang telah ditetapkan yang bertujuan untuk ketertiban berlalu lintas di jalan raya. Sehingga dibuatlah penelitian untuk melakukan produksi video motion graphic iklan layanan masyarakat mengenai edukasi tata tertib rambu lalu lintas menggunakan metode penelitian Kuantitatif dengan metode penyelesaian vaughan. Dan pada hasil analisis yang dilakukan terlihat hasil nya pada tingkat ke efektifitas yang berdasarkan interval skala likert pada ahli diperoleh predikat "Sangat Setuju" dengan nilai rata- rata 96,25\% (berdasarkan rincian aspek : Grafis 90\%, Tipografi $95 \%$, animasi $100 \%$ dan audio $100 \%$ ). Dan pada perhitungan EPIC Rate didapati sebesar 4.145 (berdasarkan rincian aspek : Empathy 4.19, Persuation 4.16, Impact 4.17, dan Communication 4.06 dan berdasarkan pertanyaan mengenai kinetic typografi yang sudah di masukkan pada kuisioner membuktikan bahwa penggunaan kinetic typografi efektif untuk dilakukan
\end{abstract}

\section{Pendahuluan}

Kendaraan bermotor ialah kendaraan yang digerakkan oleh peralatan teknik untuk pergerakkannya, dan digunakan untuk transportasi darat. Umumnya kendaraan bermotor menggunakan mesin pembakaran dalam, namun motor listrik dan mesin jenis lain (misalnya kendaraan listrik hibrida dan hibrida plug-in) juga dapat digunakan. Sepeda motor merupakan satu dari sekian banyak kendaraan bermotor yang banyak digunakan di Indonesia [1]. Penggunaan sepeda motor di Indonesia sangat populer karena harganya yang relatif murah, terjangkau bagi sebagian besar kalangan dan juga penggunaan bahan bakarnya serta biaya operasionalnya yang hemat.

Permasalahan utamanya adalah banyaknya pengendara yang kerap melakukan pelanggaran yang telah dibuat oleh undang-undang, dimana pelanggaran tersebut merupakan faktor tidak tertibnya lalu lintas dan juga salah satu faktor utama kecelakaan [2]. Di Indonesia, banyaknya pelanggaran lalu lintas sepeda motor di dominasi oleh karyawan swasta, pelajar dibawah umur dan mahasiswa. Menurut hasil evaluasi sepanjang tahun 2019 lalu disebutkan jika pelanggaran lalu lintas meningkat hingga mencapai 33\%. dan untuk pelanggaran terkait rambu lalu lintas di Batam sepanjang bulan januari 2020 sebanyak 371 [3]. Hal tersebut sangat merugikan pengendara lainnya dan dapat saja berakibat kecelakaan yang fatal.

Dari permasalahan tersebut, peneliti memiliki sebuah gagasan untuk membuat sebuah iklan layanan masyarakat berupa Video Motion Graphic dengan menggunakan jenis Kinetic Typography. Diharapkan iklan layanan masyarakat ini dapat memberikan informasi dan edukasi bagi pengendara untuk mentaati rambu-rambu lalu lintas yang telah dibuat dan disepakati. penelitian ini dibuat menggunakan metode penelitian kuantitatif dengan model pengembangan vaughan yang terdiri dari 4 tahapan yaitu perencanaan, desain dan produksi, pendistribusian, dan pengujian. selanjutnya dilakkan analisis likert terhadap 
uji ahli dan analisis EPIC model pada uji efektivitas. Tujuan dalam penelitian ini adalah menghasilkan video motion graphic yang dapat dijadikan salah satu media edukasi kepada masyarakat pengguna jalan raya, serta mengetahui seberapa efektif peran dari video ini sebagai media edukasi. diharapkan hasil penelitian ini dapat menjadi salah satu media edukasi yang bisa diberikan kepada masyarakat mengenai pentingnya mematuhi peraturan lalu lintas.

Berdasarkan masalah diatas maka penulis mencara cara bagaimana membuat sebuah motion graphic yang dapat memberikan informasi mengenai TATA TERTIB RAMBU LALU LINTAS dengan jelas dan informatif kepada masyarakat dan bagaimana melakukan analisis terhadap keefektivitasan motion graphic tersebut dalam memberikan informasi dengan menggunakan metode EPIC Model. dan Adapun juga tujuan yang ingin disampaikan dalam penyusunan tugas akhir ini adalah untuk Mengimplementasikan motion graphic sebagai video iklan layanan masyarakat dan untuk mengetahui keefektivitasan motion graphic dalam memberikan informasi kepada target penggunanya menggunakan metode EPIC Model

\section{Metode Penelitian}

a. Media Promosi

Darmastuti Memiliki pendapat bahwa media memiliki peran yang penting di masyarakat untuk menyampaikan informasi dari masyarakat di belahan dunia manapun. Media juga memiliki pengaruh negatif dan juga pengaruh positif dalam penyampaian informasi. Media juga merupakan salah satu kebutuhan manusia untuk berbagi pengetahuan, menyampaikan informasi dan untuk berkomunikasi [4].

b. Iklan

Periklanan ialah komunikasi non personal melalui beberapa media yang dibayar oleh perusahaan- perusahaan bisnis, organisasi-organisasi non profit dan individu-individu, yang berfungsi unutuk memberitahu atau membujuk anggota- anggota dari penerima pesan tertentu untuk tertarik dengan pesan yang disampaikan.[5]

c. Kinetic Typografi

Kinetic typography adalah kombinasi dari tipografi dan gerak (motion) atau biasa juga disebut sebagai typographic animation. Tidak seperti bentuk hasil cetak yang statis, kinetictypography menggunakan gerak untuk mengungkapkan gestur dengan cara yang sama efektifnya dengan citra visual. Sebagai medium, kinetic typography merupakan suatu karya multidisiplin karena dapat mengintegrasikan teknologi, tipografi, gerak, desain grafis, musik, dan narasi teks[6]

d. Kepatuhan Lalu Lintas

Kepatuhan berlalu lintas merupakan bentuk sikap patuh kepada aturan lalu lintas yang telah dibuat oleh pihakpihak tertentu. Aturan tersebut difungsikan untuk membimbing pengguna jalan agar patuh terhadap aturan yang berdampak positif untuk pengguna jalan dan mengurangi peristiwa seperti kecelakaan lalu lintas. Berdasarkan penjelasan diatas, tata tertib pada lalu lintas yang digunakan sebagai patokan materi pada video motion graphic ini adalah pelanggaran berdasarkan faktor jalan dan juga faktor manusia seperti pembagian dibawah ini:

i. Rambu-rambu lalu lintas

ii. Pemberian alat isyarat lalu lintas / lampu lalu lintas

iii. penggunaan lampu isyarat kendaraan / lampu sign

e. Populasi dan Sampel

Teknik sampling yang digunakan ialah sampling insidental. Sampling insidental adalah teknik penentuan sampel dengan secara tidak sengaja ( insidental ), sehingga sampel yang di ambil adalah siapa pun yang secara tidak sengaja atau kebetulan bertemu dengan peniliti, dengan ketentuan- ketentuan tertentu [7]

f. EPIC Model

Metode analisis yang digunakan pada iklan layanan masyarakat edukasi tata tertib lalu lintas yang menerapkan motion graphic adalah metode EPIC model. EPIC model adalah sebuah pengukur efektivitas iklan yang dikembangkan oleh AC Nielsen yaitu sebuah perusahaan peniliti pasar terkemuka dengan menggunakan pendekatan komunikasi.

\section{A. Tinjauan Pustaka}

Pengimplementasian motion graphic terhadap video iklan layanan masyarakat sudah cukup banyak dibuat. Hal tersebut pula dapat dijadikan sebagai referensi untuk mengidentifikasi penelitian ini supaya dapat dibedakan dengan penelitian lainnya. Berikut beberapa penelitian terdahulu yang digunakan untuk referensi penelitian ini :

Sasono Handito Vadly (2018) "Perancangan Motion Graphic Iklan Layanan Masyarakat Tentang Pentingnya Membayar Pajak Berbasis Infografis Sebagai Upaya Menyadarakan Masyarakat Surabaya." Menggunakan metode analisis deskriptif-kualitatif. Menghasilkan produk berupa video motion graphic yang disebarkan melalui media sosial, banner, poster, pin dan stiker.[8] 
Yunita Anggraini (2017) “Analisis dan Implementasi Motion Grafis Iklan Layanan Masyarakat Dengan Metode Semiotika Pierce.” Menggunakan metode semiotika pierce dan menghasilkan produk berupa animasi motion graphic [9] disebarluaskan dalam bentuk banner, poster, serta logo yang diimplementasikan ke baju, totebag dan topi.[10].

Penelitian ini akan di analisis keefektivitasan dari motion graphic dengan menggunakan metode EPIC Model dan hasil dari kuesioner akan di hitung menggunakan skala Likert serta akan dihitung nilai EPIC Rate untuk mengetahui tingkat keefektivitasan motion graphic yang dibuat. Kenapa penulis menggunakan EPIC model sebagai metode dikarenakan EPIC model memang metode yang dibuat cocok untuk melakukan efektivitas suatu produk yang digunakan sebagai media promosi, sosialisasi dan sejenis nya. Berikut beberapa penelitian terdahulu yang digunakan sebagai acuan penulis untuk menggunakan EPIC Model sebagai metode analisis: Tita Gracella Ham (2014) "Pengukuran Efektivitas Media Promosi Dengan Pendekatan Epic Model".[11], Dewi Rosa I., dan Zenitha Maulida (2017) "Analisis Efektivitas Iklan Media Televisi Menggunakan EPIC Model (Studi Kasus Produk A Mild di Kota Langsa)".[12], Aaron Harsono (2017) "Analisis Efektivitas Iklan Pre-Roll Youtube Lux Floral Fusion Oil Dengan Menggunakan Metode EPIC Model dan Pengaruhnya Terhadap Minat Beli Konsumen diBandung”.[13]

Penelitian ini menggunakan model pengembangan multimedia Vaughan dalam pembuatan produk motion graphic sebagai media promosi. Model pengembangan Vaughan ini memiliki 4 tahapan yaitu Perencanaan dan Pembiayaan, Desain dan Produksi, Pengujian, serta Pendistribusian. Tahapan-tahapan penelitian multimedia pada penelitian ini disajikan secara rinci pada gambar 1.

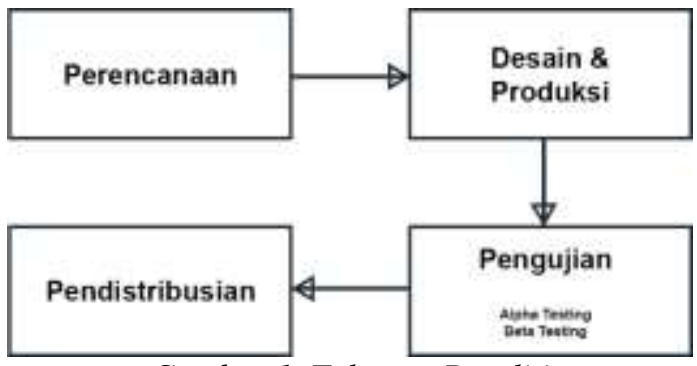

Gambar 1. Tahapan Penelitian

dan untuk metode penelitian yang dilakukan adalah menggunakan EPIC Model dengan tahapan-tahapan seperti gambar dibawah ini :

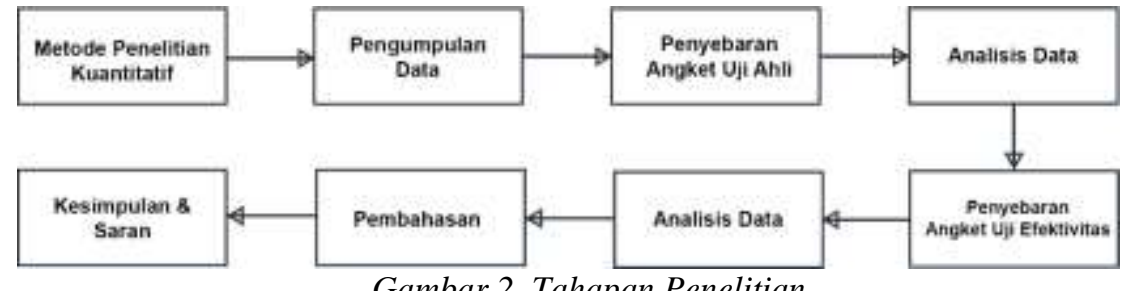

Gambar 2. Tahapan Penelitian

Dimana tahapan tersebut dilakukan dengan metode kuantitatif. Untuk pengumpulan data dilakukan penyebaran angket kepada penguji ahli, dan kemudian dilakukan analisa hasilnya. Jika sudah sesuai maka akan dilanjutkan dengan penyebaran angket kepada sampel untuk melakukan uji efektifitas. Proses selanjutnya adalah emlakukan analisa hasil pengujian sample, dan dilanjutkan dengan pembahasan dengan tim penelitian. Terakhir dibuat kesimpulan dari hasil penelitian dan pengujian.[14].

Dan pengujian terhadap kinetic typografi dilakukan pada EPIC model dimana dengan penggunaan motion kinetic ini masih dapat membuat penonton nya memahami maksud dan pesan dari video motion graphic ini baik dari segi komunikasi, empati, dan memberikan kesan persuasi untuk yang menonton nya agar melakukan dan melakukan pesan yang disampaikan.

B. Perencanaan

1) Gagasan dan Tujuan

Ide pembuatan media sosialisasi iklan yang menerapkan motion graphic ini ditujukan kepada pengendarapengendara di jalan raya terkhusus nya pengendara sepeda motor. Isi konten yang terdapat pada media sosialisasi berbasis motion graphic ini adalah memberikan pengarahan, anjuran serta bagaimana berkendara dengan baik sesuai dengan aturan dan undang-undang yang telah ditetapkan dan memberikan hukuman dan denda bagi yang tidak mentaati aturan yang telah ditetapkan. 
2) Identifikasi Kebutuhan

Durasi pada motion graphic ini akan dibuat 1 - 3 menit sehingga video dapat mencakup banyaknya informasi yang diberikan. Penggunaan motion graphic pada video ini terdiri dari gabungan beberapa elemen seperti desain grafis, teks, narasi, dan musik. Desain yang dibuat akan menggunakan aplikasi Adobe Illustrator CC dengan menggunakan Teknik tracing dari sketsa yang sudah dibuat, lalu hasil desain akan melalui proses animating, editing, dan rendering menggunakan aplikasi Adobe After Effects CC.

C. Desain dan Produksi

1) Narasi

Narasi yang ada di motion graphic ini akan berupa teks yang memberikan informasi terhadap visual pada scenescene yang ada. Teks ini cukup aktif, dikarenakan menggunakan konsep Kinetic Typography yaitu Type In Motion dan Fluid Typography yang memberikan makna yang berbeda pada setiap gerakan, dan memberikan penekanan pada aktivitas tertentu pada scene. Narasi ditunjukkan pada tabel 1 Narasi

Tabel 1. Penggalan Naskah

\begin{tabular}{c|l}
\hline Scene & Script \\
1 & Politeknik Negeri Batam \\
2 & (Karakter MUJO Muncul) \\
3 & Halo Nama Saya MUJO \\
4 & Tahukah Kalian ? \\
5 & Banyak peraturan berkendara yang sering dilanggar \\
6 & Berikut 3 pelanggaran yang sering dilakukan di indonesia \\
7 & MUJo akan membantu mengedukasi kalian tentang bahayanya \\
8 & melanggar peraturan berkendara \\
9 & Lenjelasan Lampu Lalu Lintas) \\
& bergu lalu lintas adalah alat pemberi isyarat lalu lintas yang \\
& persimpangan jalan, tempat penyeberangan pejalan kaki, dan \\
\hline
\end{tabular}

2) Storyboard

Pada tahap ini adalah pembuatan storyboard yang dirancang untuk pembuatan motion graphic edukasi tata tertib rambu lalu lintas Storyboard terdiri dari 20 scene yang dapat dilihat pada tabel 2 penggalan dari storyboard.

Tabel 2. Penggalan Storyboard

\begin{tabular}{|c|c|c|}
\hline Scene & Gambar & Aksi \\
\hline 1 & & Logo Politeknik muncul dengan transisi : Fade In \\
\hline 2 & & Karakter "MUJO" muncul dari kanan \\
\hline 3 & $\begin{array}{l}\text { HALO } \\
\text { NAMA SAYA } \\
\text { MUSO }\end{array}$ & $\begin{array}{l}\text { Karakter "MUJO" memperkenalkan diri } \\
\text { Teks muncul dari kiri (menggunakan jenis kinetic Type In } \\
\text { Motion : Scrolling Typography) }\end{array}$ \\
\hline
\end{tabular}

\section{HASil dan Pembahasan}

Ada 2 bagian pembahasan di bagian ini yaitu pembahasan hasil video motion graphic yang di buat dan juga hasil dari analisis yang dilakukan yaitu analisis pada alpha dan beta testing. 
4.1 Sketsa dan Tracing Asset

Proses yang dilakukan pada tahap ini adalah membuat objek dari sketsa yang telah dibuat menjadi bentuk digital dengan menggunakan aplikasi Adobe Illustrator CC 2018. Asset yang digunakan ada 8 asset seperti karakter lampu lalu lintas, lampu lalu lintas, rambu lalu lintas, dan icon politeknik negeri batam.

\subsection{Animating}

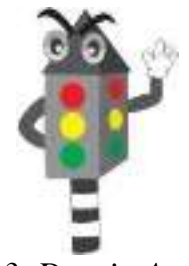

Gambar 3. Desain Asset

Setelah membuat asset yang telah di tracing dan pewarnaan, langkah selanjutnya adalah membuat animasi dari objek-objek yang telah ada menggunakan Adobe After Effect CC 2018. Efek yang diberikan seperti pengubahan dari scale, rotation, position, opacity, dan juga menggunakan 3D kamera yang telah diberikan pada fitur aplikasi ini seperti yang ditunjukkan pada gambar 4.

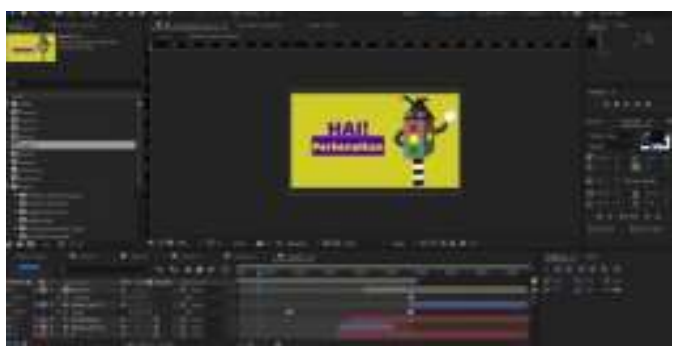

Gambar 4. Proses Animasi

4.3 Proses Editing

Setelah membuat animasi, langkah selanjutnya adalah menggabungkan tiap animasi dan scene serta memasukkan audio effect dan backsound menggunakan aplikasi adobe premiere CC 2018, seperti yang ditunjukkan pada gambar 5.

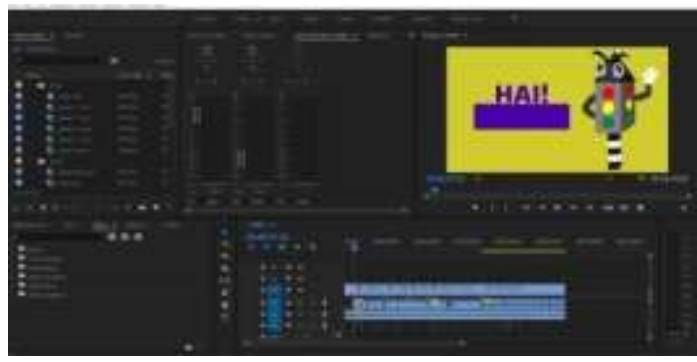

Gambar 5. Proses Editing

4.4 Proses Rendering

Langkah terakhir yaitu melakukan rendering terhadap video yang telah selesai, proses ini dilakukan Ketika proses editing telah selesai dilakukan. Rendering menggunakan software Adobe Premiere CC 2018 seperti yang terlihat pada gambar 6

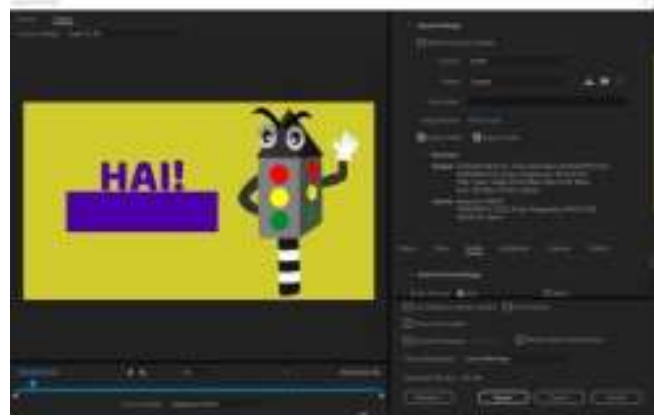


4.5 Pengujian Data

\section{Gambar 6 Proses Rendering}

Proses yang dilakukan pada tahapan ini adalah tahap dalam melakukan pengujian yang menggunakan teknik Uji Ahli dan Uji Efektivitas EPIC Model. Berikut merupakan gambar tahapan pengujian alpha testing dan beta testing. Dimana tahapan tersebut dilakukan dengan metode kuantitatif. Untuk pengumpulan data dilakukan penyebaran angket kepada penguji ahli, dan kemudian dilakukan analisa hasilnya. Jika sudah sesuai maka akan dilanjutkan dengan penyebaran angket kepada sampel untuk melakukan uji efektifitas. Proses selanjutnya adalah emlakukan analisa hasil pengujian sample, dan dilanjutkan dengan pembahasan dengan tim penelitian. Terakhir dibuat kesimpulan dari hasil penelitian dan pengujian

1) Uji Ahli

Pada pengujian yang dilakukan kepada ahli media yaitu Rahmat dany suhery S.Ds dan Rizki Novrizal S.Ds, pengujian dilakukan adalah mengenai kelengkapan unsur-unsur dalam motion graphic yang terdapat pada penelitian ini dengan cara penyebaran angket. Adapun aspek-aspek yang akan di uji pada pengujian ahli media terdapat di tabel 3 Aspek-aspek pengujian ahli media

Tabel 3. Aspek Uji Ahli

\begin{tabular}{|c|l|c|c|}
\hline Aspek & \multicolumn{1}{|c|}{ Instrumen } & Soal ke- & Jumlah Soal \\
\hline \multirow{2}{*}{ Grafis } & Kualitas Desain dan Tracing & 1 & 1 \\
\cline { 2 - 4 } & Posisi dan Ukuran & 2 & 1 \\
\hline Tipografi & Pemilihan Font & 3 & 1 \\
\cline { 2 - 4 } & Posisi dan Ukuran & 4 & 1 \\
\hline Animasi & Kecepatan dan Ketepatan Pergerakan Animasi & 5,6 & 2 \\
\hline Audio & Ketepatan Suara Musik dan Suara Narasi & 7,8 & 2 \\
\hline
\end{tabular}

Setelah dilakukan wawamcara terhadap ahli menggunaan wawancara terstruktur didapatkan sebuah hasil seperti pada tabel rekap jawaban dibawah ini

Tabel 4. Jawaban ahli 1

\begin{tabular}{|c|l|c|c|}
\hline Aspek & \multicolumn{1}{|c|}{ Instrumen } & Soal ke- & Jawaban \\
\hline \multirow{2}{*}{ Grafis } & Kualitas Desain dan Tracing & 1 & 5 \\
\cline { 2 - 4 } & Posisi dan Ukuran & 2 & 5 \\
\hline Tipografi & Pemilihan Font & 3 & 5 \\
\cline { 2 - 4 } & Posisi dan Ukuran & 4 & 5 \\
\hline Animasi & Kecepatan dan Ketepatan Pergerakan Animasi & 5 & 5 \\
\hline Audio & Ketepatan Suara Musik dan Suara Narasi & 6 & 5 \\
\cline { 2 - 4 } & & 8 & 5 \\
\hline
\end{tabular}

Tabel 5. Jawaban ahli 2

\begin{tabular}{|c|l|c|c|}
\hline Aspek & \multicolumn{1}{|c|}{ Instrumen } & Soal ke- & Jawaban \\
\hline \multirow{2}{*}{ Grafis } & Kualitas Desain dan Tracing & 1 & 4 \\
\cline { 2 - 4 } & Posisi dan Ukuran & 2 & 5 \\
\hline \multirow{2}{*}{ Tipografi } & Pemilihan Font & 3 & 4 \\
\cline { 2 - 4 } & Posisi dan Ukuran & 4 & 4 \\
\hline & Kecepatan dan Ketepatan Pergerakan Animasi & 5 & 5 \\
\hline
\end{tabular}




\begin{tabular}{|c|c|c|c|}
\cline { 3 - 4 } Animasi & & 6 & 5 \\
\hline \multirow{2}{*}{ Audio } & Ketepatan Suara Musik dan Suara Narasi & & \\
\hline
\end{tabular}

A. Aspek Grafis

Pada Aspek Grafis terdapat dua pernyataan yaitu soal ke 1 dan 2. Dan setelah dilakukan perhitungan nilai index didapatkan $90 \%, 100 \%$, dan didapatkan rata-rata sebesar 95\% dan termasuk dalam dalam kategori "sangat setuju".

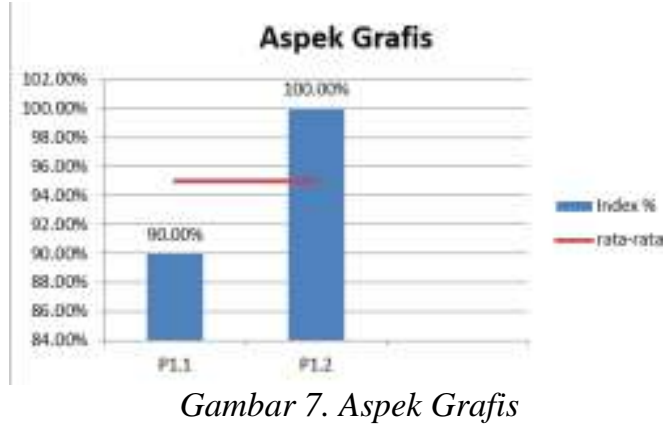

B. Aspek Tipografi

Pada Aspek Tipografi terdapat dua pernyataan yaitu soal ke 1 dan 2. Dan setelah dilakukan perhitungan nilai index didapatkan $90 \%, 90 \%$, dan didapatkan rata-rata sebesar $90 \%$ dan termasuk dalam dalam kategori "sangat setuju".

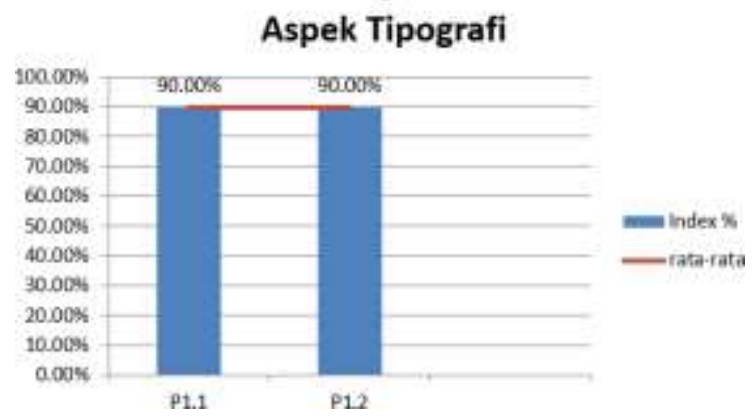

Gambar 8. Aspek Tipografi

C. Aspek Animasi

Pada Aspek Animasi terdapat dua pernyataan yaitu soal ke 1 dan 2. Dan setelah dilakukan perhitungan nilai index didapatkan $100 \%, 100 \%$, dan didapatkan rata-rata sebesar $100 \%$ dan termasuk dalam dalam kategori "sangat setuju".

\section{Aspek Animasi}

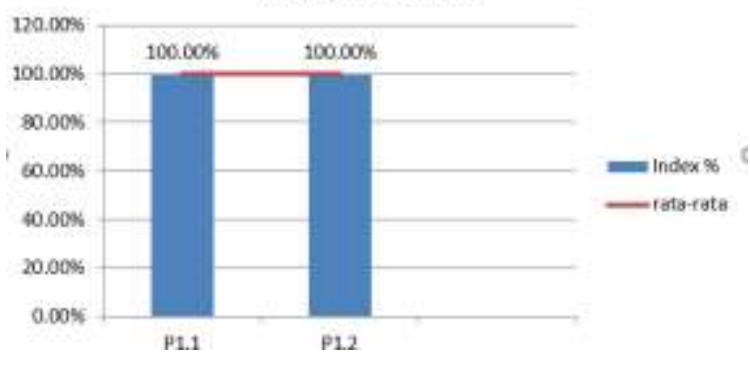

Gambar 9. Aspek Animasi 
D. Aspek Audio

Pada Aspek Audio terdapat dua pernyataan yaitu soal ke 1 dan 2. Dan setelah dilakukan perhitungan nilai index didapatkan 100\%, 100\%, dan didapatkan rata-rata sebesar 100\% dan termasuk dalam dalam kategori "sangat setuju".

\section{Aspek Audio}

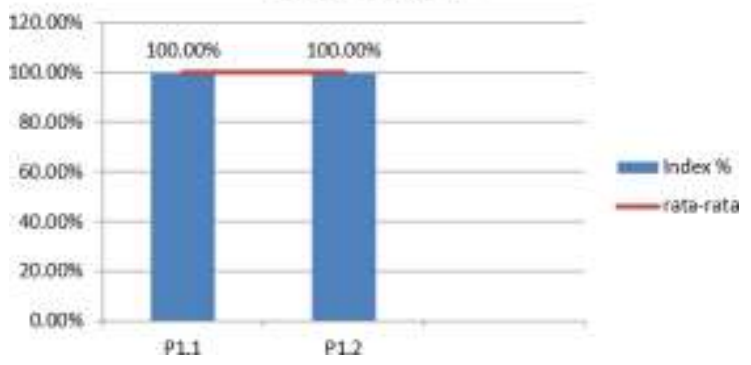

2) Uji Efektivitas

Gambar 10 Aspek Audio

Tujuan pengujian merupakan masyarakat Batam yang merupakan pengendara sepeda motor dimulai dari umur 19 tahun hingga 50 tahun dengan cara penyebaran angket terhadap 30 responden. Analisis pada tahap beta testing ini adalah menggunakan metode EPIC Model yang bertujuan untuk menguji tingkat efektivitas media iklan masyarakat edukasi tata tertib lalu lintas melalui motion graphic. Aspek- aspek pengujian tahap beta testing ditunjukkan pada tabel 6 Aspek-aspek beta testing

Tabel 6. Aspek Pengujian Efektivitas

\begin{tabular}{|c|c|c|c|}
\hline No & Aspek & Instrumen & $\begin{array}{c}\text { Soal } \\
\text { ke- }\end{array}$ \\
\hline \multirow{3}{*}{1} & \multirow{3}{*}{ Empathy } & Menurut Saya, Informasi yang diberikan meninggalkan Kesan. & 1 \\
\hline & & Menurut Saya, Informasi yang diberikan mudah dimengerti. & 2 \\
\hline & & $\begin{array}{l}\text { (Optional) Menurut Saya, Informasi yang ingin disampaikan dengan } \\
\text { menggunakan Teknik Kinetic Typography telah terealisasi. }\end{array}$ & 3 \\
\hline \multirow{3}{*}{2} & \multirow{3}{*}{ Persuation } & $\begin{array}{l}\text { Memberi Keyakinan dan Kepercayaan terhadap informasi yang } \\
\text { diberikan. }\end{array}$ & 4 \\
\hline & & $\begin{array}{l}\text { Menurut Saya, Informasi yang diberikan membuat saya ingin } \\
\text { mentaati peraturan. }\end{array}$ & 5 \\
\hline & & $\begin{array}{l}\text { (Optional) Teknik Kinetic Typography yang digunakan telah } \\
\text { memberikan saya Keyakinan dan Kepercayaan terhadap informasi } \\
\text { yang ada. }\end{array}$ & 6 \\
\hline \multirow{3}{*}{3} & \multirow{3}{*}{ Impact } & $\begin{array}{l}\text { Menurut Saya, saya merasa teredukasi terhadap informasi yang telah } \\
\text { diberikan. }\end{array}$ & 7 \\
\hline & & $\begin{array}{l}\text { Menurut Saya, Informasi yang diberikan telah membuat saya } \\
\text { mentaati peraturan yang ada. }\end{array}$ & 8 \\
\hline & & $\begin{array}{l}\text { (Optional) Menurut Saya, Teknik Kinetic Typography yang } \\
\text { digunakan mampu mengedukasi saya untuk mentaati rambu lalu } \\
\text { lintas }\end{array}$ & 9 \\
\hline & & Menurut Saya, informasi yang diberikan tersampaikan dengan jelas & 10 \\
\hline
\end{tabular}




\begin{tabular}{|l|l|l|l|}
\cline { 3 - 4 } & \multirow{4}{*}{4} & $\begin{array}{l}\text { Menurut Saya, Motion Graphic tersebut memberikan informasi } \\
\text { Cengan jelas, daripada Motion Graphic yang lain }\end{array}$ & 11 \\
\cline { 3 - 4 } & Commication & $\begin{array}{l}\text { Menurut Saya, Informasi yang diberikan membuat saya lebih } \\
\text { mengerti betapa pentingnya peraturan yang telah dibuat. }\end{array}$ & 12 \\
\hline & $\begin{array}{l}\text { (Optional) Menurut Saya, menggunakan Teknik Typography dapat } \\
\text { memberikan informasi dengan jelas }\end{array}$ & 13 \\
\hline
\end{tabular}

Dan untuk skala EPIC model yang menjadi patokan penilaian hasil nya adalah seperti tabel dibawah ini

Tabel 7. Kategori EPIC Model

\begin{tabular}{|l|c|}
\hline \multicolumn{1}{|c|}{ Kategori } & Skala \\
\hline Sangat Tidak Efektif & $1.00-1.80$ \\
\hline Tidak Efektif & $1.81-2.60$ \\
\hline Cukup Efektif & $2.61-3.40$ \\
\hline Efektif & $3.41-4.20$ \\
\hline Sangat Efektif & $4.21-5.00$ \\
\hline
\end{tabular}

1. Empathy

Bedasarkan pernyataan yang telah ada mendapatkan nilai sebesar 4.06, 4.5 dan 4.01 lalu dilakukan perhitungan rata-rata sehingga mendapatkan nilai 4.16 dan masuk kategori "Efektif"

$\prod_{5,00}$ SE $\prod_{4,21}$ E $\prod_{3,41}$ CE $\prod_{2,61}$ TE $\left.\right|_{1,81}$ SII $\prod_{1,00}$

2. Persuation

Pada aspek ini terdapat dua pernyataan yang dimana tiap pernyataan mendapatkan nilai sebesar 4.3, 4.2 dan 3.98 lalu dilakukan perhitungan rata-rata sehingga mendapatkan nilai 4.19 dan masuk kategori "Sangat Efektif"

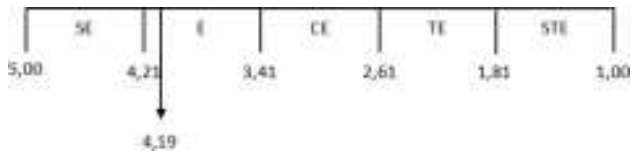

3. Impact

Bedasarkan pernyataan yang telah ada mendapatkan nilai sebesar 4.07, 4.12 dan 4.32 lalu dilakukan perhitungan rata-rata sehingga mendapatkan nilai 4.17 dan masuk kategori "Sangat Efektif"

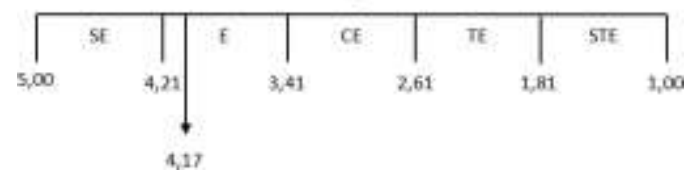

4. Communication

Bedasarkan pernyataan yang telah ada mendapatkan nilai sebesar 3.93, 4.1, 4.32 dan 3.89 lalu dilakukan perhitungan rata-rata sehingga mendapatkan nilai 4.06 dan masuk kategori "Sangat Efektif"

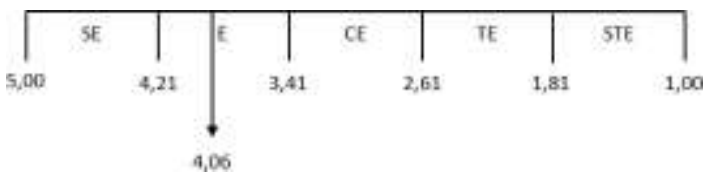

5. EPIC Rate 
Selanjut nya adalah untuk menentukan EPIC Rate dengan mengkalkulasi hasil rata-rata yang telah didapatkan. Dan didapatkan nilai sebesar 4.145 dimana termasuk dalam rentang "Sangat Efektif"

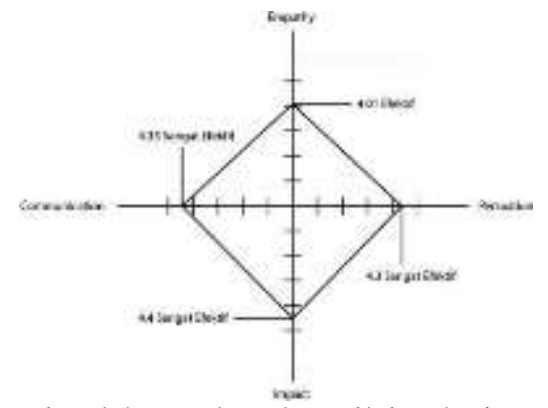

Setelah masing-masing dimensi sudah mendapatkan nilai, selanjutnya adalah menghitung EPIC Rate. EPIC Rate adalah rata-rata dari nilai 4 dimensi yang sudah didapat sebelumnya. Nilai-nilai tiap dimensi yang sudah didapat akan ditunjukkan pada Tabel 4.13 Nilai dimensi EPIC Model.

Tabel 8. Nilai dimensi EPIC Model

\begin{tabular}{|l|c|c|}
\hline \multicolumn{1}{|c|}{ EPIC MODEL } & Nilai & Keterangan \\
\hline Empathy & 4,16 & Efektif \\
\hline Persuation & 4,19 & Efektif \\
\hline Impact & 4,17 & Efektif \\
\hline Communication & 4,06 & Efektif \\
\hline
\end{tabular}

EPIC Rate $=4,16+4,19+4,17+4,06 / 4=4,15$

Hal ini mengindikasikan bahwa video motion yang dibuat, disukai oleh penonton, menarik perhatian, mampu membujuk dan meyakinkan penonton untuk menaati peraturan, memberi ilmu pengetahuan baru mengenai peraturan berkendara serta informasi yang disampaikan jelas dan mudah dimengerti.

4.6 Pendistribusian

Pada tahap delivery, akan dilakukan penyebarluasan video motion yang telah dibuat, melalui media online yaitu youtube. seperti pada gambar 11 Youtube Iklan Peraturan Rambu lalu lintas

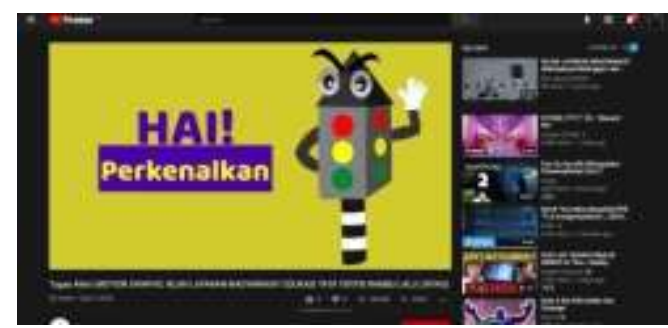

Gambar 11 Youtube Iklan Peraturan Rambu lalu lintas

\section{KESIMPULAN}

Berdasarkan hasil penelitian yang telah dilakukan dalam penulisan tugas akhir ini, maka dapat diambil beberapa kesimpulan diantaranya :

1. Pembuatan video yang menggunakan kinetic tipografi dan dengan mengimplementasikan aspek motion graphic sebagai media edukasi rambu lalu lintas menjadi bahan edukasi yang tepat karena lebih mudah dipahami dan efektif dalam penyampaian informasi kepada masyarakat luas terkhusus nya pengendara.

2. Pembuatan video yang menggunakan kinetic tipografi dan dengan mengimplementasikan aspek motion graphic sebagai media edukasi rambu lalu lintas telah dilakukan dan memiliki tingkat ke efektifitas yang berdasarkan interval skala likert pada ahli diperoleh predikat "Sangat Setuju" dengan nilai rata-rata 96,25\% (berdasarkan rincian aspek : Grafis 90\%, Tipografi 95\%, animasi 100\% dan audio 100\%). Semua itu berdasarkan aspek-aspek dari motion graphic pada kinetic typografi yang penulis masukkan pada kuisioner

3. Hasil penelitian telah berhasil menyelesaikan tujuannya yaitu menghasilkan video motion graphic yang dapat mengedukasi masyarakat pengguna jalan raya, serta mengetahui seberapa efektif peran dari video ini sebagai 
media edukasi. hal ini dapat dilihat dari perhitungan EPIC Rate didapati sebesar 4.145 (berdasarkan rincian aspek : Empathy 4.19, Persuation 4.16, Impact 4.17, dan Communication 4.06).

4. Berdasarkan dari uji ahli dan EPIC yang telah dilakukan penulis terhadap produk motion graphic ini memberikan sebuah kesimpulan bahwa video motion graphic ini sudah bisa digunakan sebagai iklan layanan masyarakat dalam kesadaran atas tata tertib lalu lintas secara online melalui platform youtube.

\section{Daftar Pustaka}

[1] CV. News, T. (2020) Angka Pelanggaran Lalu Lintas di Batam Masih Tinggi. Tersedia pada: https://batam.tribunnews.com/2020/02/04/.

[2] HaluanKepri.com (2019) Hari Pertama Razia, 109 Kendaraan Ditilang. Tersedia pada: https://haluankepri.com/2019/10/24/hari-pertama-razia-109-kendaraan-ditilang/.

[3] Narita, T. dan Suyanto, A. (2019) Analisa Efektivitas Iklan Web Series Dengan Menggunakan Epic Model. 3(1). Jurnal Mitra Manajemen.

[4] Darmastuti, R. 2012. Media Relations: Konsep, Strategi, dan Aplikasi. Andi Publisher

[5] Shri Isyanahapsari. (2018) Pengaruh Periklanan dan Kualitas Pelayanan Terhadap Keputusan Pembelian Secara Online Pada Situs Belanja Online.

[6] Pratama Yudi. (2020) Implementasi Teknik Kinetik Tipografi sebagai Media Informasi untuk Gajadmada Digital Printing.

[7] Sugiyono (2017) Metode Penelitian Kuantitatif, Kualitatif, dan R\&D. Bandung: Alfabeta.

[8] Sasono Handito Vadly. (2018) Perancangan Motion Graphic Iklan Layanan Masyarakat Pentingnya Membayar Pajak Berbasis Infografis. Institut Bisnis dan Informatika Stikom Surabaya.

[9] Yunita Anggraini. (2017) Analisis dan Implementasi Motion Grafis Iklan Layanan Masyarakat Dengan Metode Semiotika Pierce. Institut Teknologi Bandung

[10] Rayhan Helsa Fajri. (2018) Perancangan Motion Graphic Sebagai Iklan Layanan Pentingnya Imunisasi Bagi Anak Sejak Usia Dini Di Kota Bukittinggi.

[11] Tita Gracella Ham (2014) Pengukuran Efektivitas Media Promosi Dengan Pendekatan Epic Model.

[12] Dewi Rosa I., dan Zenitha Maulida (2017) Analisis Efektivitas Iklan Media Televisi Menggunakan EPIC Model (Studi Kasus Produk A Mild di Kota Langsa).

[13] Aaron Harsono (2017) Analisis Efektivitas Iklan Pre-Roll Youtube Lux Floral Fusion Oil Dengan Menggunakan Metode EPIC Model dan Pengaruhnya Terhadap Minat Beli Konsumen di Bandung.

[14] Sugiyono, D. (2010) Metode Penelitian Kuantitatif dan R\&D. Bandung: Alfabeta. 